Article

\title{
Genetic Subtyping, Biofilm-Forming Ability and Biocide Susceptibility of Listeria monocytogenes Strains Isolated from a Ready-to-Eat Food Industry
}

\author{
Joana Catarina Andrade ${ }^{1}$ (D), António Lopes João ${ }^{2}$, Carlos de Sousa Alonso ${ }^{2}$, \\ António Salvador Barreto ${ }^{1}$ and Ana Rita Henriques ${ }^{1, * \mathbb{D}}$ \\ 1 CIISA-Centre for Interdisciplinary Research in Animal Health, Faculty of Veterinary Medicine, \\ University of Lisbon, 1300-477 Lisbon, Portugal; ajoanacatarina@gmail.com (J.C.A.); \\ asbarreto@fmv.ulisboa.pt (A.S.B.) \\ 2 Laboratório de Bromatologia e Defesa Biológica do Exército, 1849-012 Lisbon, Portugal; \\ joao.aebl@exercito.pt (A.L.J.); alonso.ces@exercito.pt (C.d.S.A.) \\ * Correspondence: anaritah@fmv.ulisboa.pt; Tel.: +351-213-652-834
}

Received: 25 June 2020; Accepted: 15 July 2020; Published: 16 July 2020

\begin{abstract}
Listeria monocytogenes is a foodborne pathogen of special concern for ready-to-eat food producers. The control of its presence is a critical step in which food-grade sanitizers play an essential role. L. monocytogenes is believed to persist in food processing environments in biofilms, exhibiting less susceptibility to sanitizers than planktonic cells. This study aimed to test the susceptibility of L. monocytogenes in planktonic culture and biofilm to three commercial food-grade sanitizers and to benzalkonium chloride; together with the genetic subtyping of the isolates. L. monocytogenes isolates were collected from raw materials, final products and food-contact surfaces during a 6-year period from a ready-to-eat meat-producing food industry and genetically characterized. Serogrouping and pulsed-field gel electrophoresis (PFGE) revealed genetic variability and differentiated L. monocytogenes isolates in three clusters. The biofilm-forming ability assay revealed that the isolates were weak biofilm producers. L. monocytogenes strains were susceptible both in the planktonic and biofilm form to oxidizing and ethanol-based compounds and to benzalkonium chloride, but not to quaternary ammonium compound. A positive association of biofilm-forming ability and $\mathrm{LD}_{90}$ values for quaternary ammonium compound and benzalkonium chloride was found. This study highlights the need for preventive measures improvement and for a conscious selection and use of sanitizers in food-related environments to control Listeria monocytogenes.
\end{abstract}

Keywords: biocide; Listeria monocytogenes; biofilm; planktonic culture; pulsed-field gel electrophoresis

\section{Introduction}

Listeria monocytogenes is an ubiquitous small Gram-positive bacterium widespread in the natural environment [1]. It is also an opportunistic pathogen responsible for human listeriosis, a severe disease with high hospitalization and case fatality rates [2,3]. Its psychrotrophic nature and the ability to survive and multiply under extreme physicochemical conditions [4] may explain the difficulty of controlling its presence in refrigerated environments [5].

This pathogen is often associated to ready-to-eat (RTE) food products, with contamination occurring during food processing production [6,7]. Incoming raw materials, food handlers, and even processed ingredients and products are frequent sources of L. monocytogenes contamination [8]. After entering a food producing facility, L. monocytogenes can become a long-term resident, being able to persist for months or years within the premises, including food contact equipments [9]. Once established, 
L. monocytogenes biofilms can persist, resulting in the potential continuous contamination of the food products [10].

L. monocytogenes has the ability to adhere to different surfaces within the food industry, such as plastic, rubber, stainless steel, glass, and produce biofilms [5,11]. Biofilm formation is affected by many factors, such as strain-specific properties, composition of the attachment surface, and environmental conditions [12]. Previous works relating L. monocytogenes serotypes and biofilm formation remained inconclusive, although several authors have addressed it [13-16].

In the biofilm, bacteria are embedded by an extracellular matrix able to function as a structural scaffold and protective barrier against various stresses and antimicrobials, like those encountered in the food processing environment [13,17]. Biofilms are associated to increased resistance to sanitizing compounds, due to bacterial exposure to sublethal biocide concentrations, acquiring resistance to antimicrobials over time $[17,18]$.

The validation of sanitizers is essential to avoid the misuse of biocides that may end-up promoting resistance of L. monocytogenes virulent strains. Still, the effectiveness of commercial food-grade sanitizers is tested on planktonic microorganisms, but the biofilm environment may change the response of every strain involved [19]. Among food-grade sanitizers used in RTE food processing premises, oxidizing disinfectants and quaternary ammonium compounds are the most popular, due to their broad-spectrum activity against bacteria, high efficacy and low cost [20,21]. Nevertheless, L. monocytogenes resistance to these compounds has been described, whether in planktonic cultures or in biofilms [10,22]. The same was reported for benzalkonium chloride, a quaternary ammonium compound [23-25].

In this work, the susceptibility of L. monocytogenes in planktonic culture and biofilm to three commercial food-grade sanitizers and to benzalkonium chloride was assessed. For that, L. monocytogenes isolates collected from a RTE food-producing industry during a 6-year period were genetically characterized and their biofilm-forming ability was assessed, prior to biocide susceptibility testing.

\section{Results and Discussion}

\subsection{Characterization of L. monocytogenes Isolates Collection}

The overall proportion of positive samples (food and food related environment) contaminated by L. monocytogenes was $26.3 \%$ (20/76) (Table 1). This high percentage is in line with other studies in Portugal [26] that reported $25 \%$ of positive samples in ham, $11.1 \%$ in blood sausage and $2.3 \%$ in dry cured ham collected from producers and retailers.

\subsection{L. monocytogenes Confirmation and Serogrouping by PCR}

All of the L. monocytogenes presumptive isolates $(n=20)$ obtained by conventional microbiological methods belonged to the Listeria genus, but only 17 were confirmed as L. monocytogenes by PCR [27]. Among these 17 isolates, four different molecular serogroups were identified (Table 2).

Most of the isolates belonged to serogroup IIc (52.9\%), followed by serogroup IIa (35.3\%), $\mathrm{IIb}$ and IVb (each with 5.9\%). In line with our results, other authors have reported similar findings. Lotfollahi et al. [28] found serogroup IIc to be the most prevalent in L. monocytogenes isolates from several foods retailed in Iranian markets. In another study, Montero et al. [29] found serogroup IIa to be the most common one in RTE meat-based products collected from different retail stores and industrial processing plants in Santiago, Chile, although serogroup IIb, IIc and IVb strains were also present. In an investigation assessing serogroup diversity of L. monocytogenes isolates in food from central and northern regions in Italy, $67.5 \%$ of isolates belonged to serogroup IIa [30]. Rodríguez-López et al. [31] reported similar results in samples collected from different food-related premises in Northwest Spain during 2010 and 2011, of which only 5.9\% of isolates belonged to serogroup IVb. Torresi et al. [32] reported a predominance of serogroup IIa and IIc strains in several different cheeses in Italy.

Molecular serotyping is a rapid and useful method for first-level characterization of L. monocytogenes [16]. Still, to allow for a more reliable characterization of strains and contamination 
routes investigation, other molecular subtyping methods, such as pulsed-field gel electrophoresis (PFGE) should be used [33].

Table 1. Samples collected in the assessed industry with positive L. monocytogenes detection by conventional microbiological methods.

\begin{tabular}{ccc}
\hline Date of Collection & Sample Description/Type & $\begin{array}{c}\text { Presumptive } \\
\text { L. monocytogenes } \\
\text { Isolate Code }\end{array}$ \\
\hline July 2010 & Chourição/Final product & FP1 \\
February 2013 & Chouriço/Final product & FP2 \\
March 2013 & Seasoned ham meat/Intermediate product & IP1 \\
March 2013 & In-use meat mincing machine/Equipment & E1 \\
March 2013 & Meat sausage/Final product & FP3 \\
April 2013 & Unseasoned ham meat/Intermediate product & IP2 \\
April 2013 & Seasoned ham meat/Intermediate product & IP3 \\
April 2013 & Pork meat/Raw material & RM1 \\
April 2013 & In-use meat mincing machine/Equipment & E2 \\
April 2013 & Raw meat transport box/Equipment & E3 \\
July 2013 & Pork meat/Raw material & RM2 \\
October 2013 & Chouriço/Final product & FP4 \\
February 2014 & Lard for chouriço/Raw material & RM3 \\
February 2014 & Chouriço/Final product & FP5 \\
April 2014 & RM4 \\
May 2014 & Chouriço/Final product & FP6 \\
May 2014 & Alheira/Final product & FP7 \\
January 2015 & Foneless pork shoulder/Raw material & RM5 \\
February 2015 & Chouriço/Final product & FP8 \\
April 2015 & FP9 \\
\hline
\end{tabular}

Table 2. Description of the obtained serogroups among L. monocytogenes confirmed isolates $(n=17)$.

\begin{tabular}{ccc}
\hline Serogroup & Proportion & Isolate Code ${ }^{1}$ \\
\hline IIa & $6(35.3 \%)$ & FP1, RM2, RM3, FP7, FP8, FP9 \\
Ilb & $1(5.9 \%)$ & FP5 \\
IIc & $9(52.9 \%)$ & FP2, IP1, E1, FP3, IP2, RM1, E2, E3, RM4 \\
IVb & $1(5.9 \%)$ & RM5 \\
\hline L. monocytogenes isolates share the same code with the sample from which they were recovered.
\end{tabular}

\subsection{Pulsed-Field Gel Electrophoresis Typing}

Figure 1 presents the resulting dendrogram of 17 L. monocytogenes strains considering ApaI and $A s c \mathrm{I}$ restriction patterns and serogroups. Pulsotypes were considered to be clones when they had at least $90 \%$ of similarity.

The different food and environment samples presented six PFGE types. Three clusters were identified (indicated as A, B and C in Figure 1), while FP5, RM5 and FP1 pulsotypes had a distinct PFGE profile.

The first cluster (Figure 1, cluster A) includes 9 strains, corresponding to $52.9 \%$ of all the analyzed isolates. These strains with identical restriction patterns and exhibiting the same serogroup (serogroup IIc) were collected from raw materials, intermediate products, finished products, and food-contact surfaces in a time frame of 14 months (from February 2013 to April 2014). When comparing cluster A food-contact surfaces and finished products strains' profiles, results suggest the possibility of a common source. It is noteworthy that L. monocytogenes strain RM4 collected in 2014 has $91.6 \%$ similarity with strains collected in 2013. This is suggestive of a potential persistent contamination within the food industry, although more studies should be considered in order to establish source attribution. 
Kurpas et al. [34] linked L. monocytogenes presence in food processing environments, such as abattoirs, RTE meat-processing industries and retail establishments to cross-contamination.

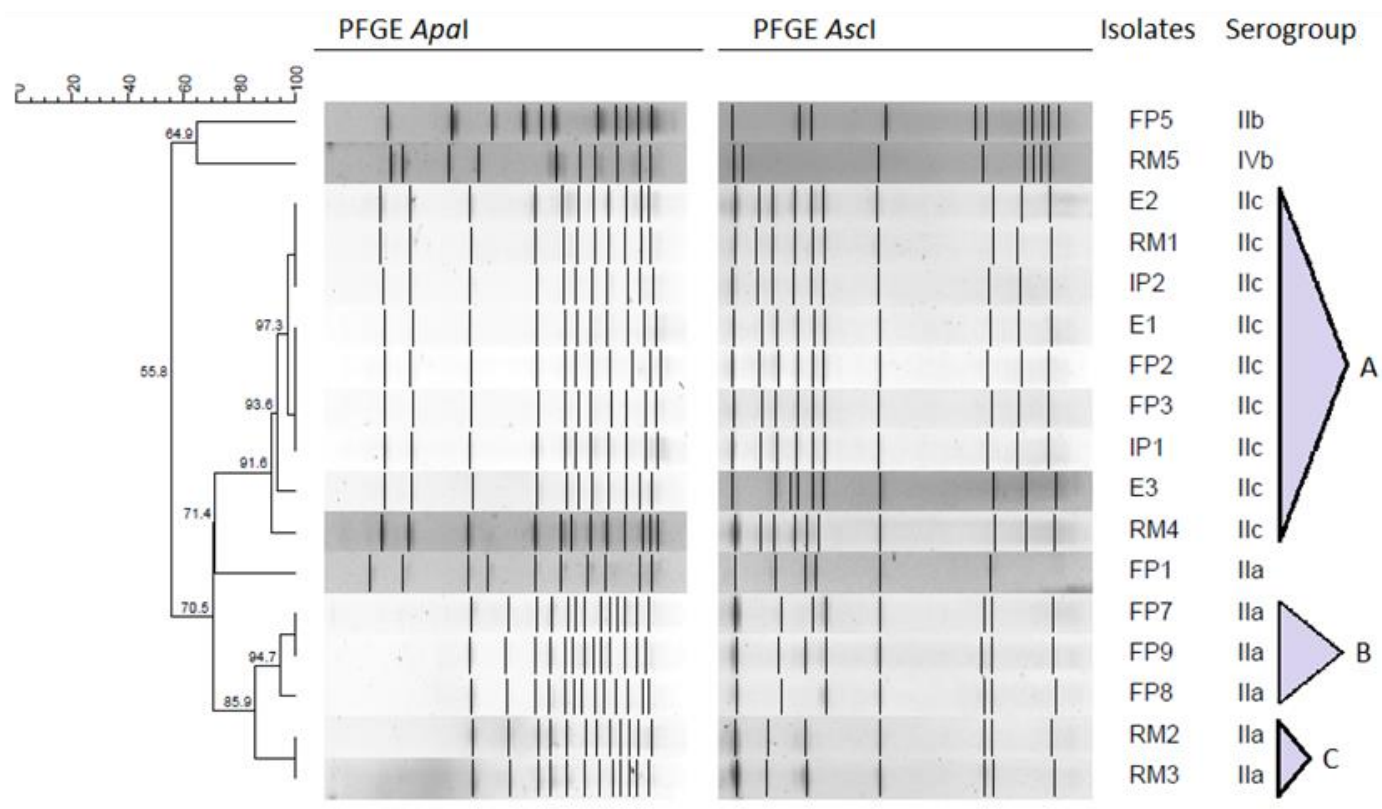

Figure 1. Dendrogram of the ApaI-AscI PFGE profiles and corresponding serogroup for 17 L. monocytogenes selected isolates.

Cluster B includes three strains (FP7, FP8 and FP9) collected from different finished products between May 2014 and April 2015, all belonging to serogroup IIa. L. monocytogenes strain FP7 shares an indistinguishable profile with strain FP9, collected 1 year later. Apart from being suggestive of persistence over time, which might be due to L. monocytogenes survival and growth in niches within the food environment, these strains belong to serogroup IIa, which is the one most commonly associated to food-related environments [1,30].

Cluster C includes 2 strains (RM2 and RM3) collected between 2013 and 2014, from different raw materials. As seen before in cluster A, L. monocytogenes pulsotypes identified in raw materials exhibit high similarity with pulsotypes from equipment and finished products. These pulsotypes may persist due to the repeated re-introduction of strains from the external environment into food processing facilities over time [35]. Suppliers should be addressed to understand the origin of some strains, although results underline cross-contamination as a possible way of disseminating L. monocytogenes in the assessed food industry. A strict selection and control of suppliers seems to be a preventive measure of upmost importance [36]. Three distinct pulsotypes can also be seen in the resulting dendrogram. FP5 and RM5 strains were collected 1 year apart from each other and presented distinct pulsotypes (64.9\% of similarity), belonging to serogroups IIb and IVb, respectively. FP1 isolate exhibits a different PFGE profile from other serogroup IIa strains (71.4\% of similarity), which might be due to the fact that serogroup IIa includes atypical strains [27,37].

The presence of serogroups IIa, IIb and IVb isolates suggests a potential public health hazard associated with these RTE meat-based products consumption, since these are the serogroups more commonly associated to human infection [38,39].

\subsection{Biofilm Formation Assay}

After serogrouping and PFGE typing, 10 L. monocytogenes strains were selected for the biofilm formation assay in order to have representatives with different profiles (serogroups and pulsotypes). L. monocytogenes CECT 4031, CECT 911, CECT 935, and CECT 937 were also included in order to investigate differences between strains of different serogroups. 
The assessed strains in biofilms revealed cvOD values ranging from $0.068 \pm 0.001$ to $0.1240 \pm 0.006$ and viable cell counts of $6.0 \pm 0.4 \log \mathrm{cfu} / \mathrm{mL}$ to $7.6 \pm 0.4 \log \mathrm{cfu} / \mathrm{mL}$ after 5 days of growth in polystyrene microtiter wells (Figure 2).

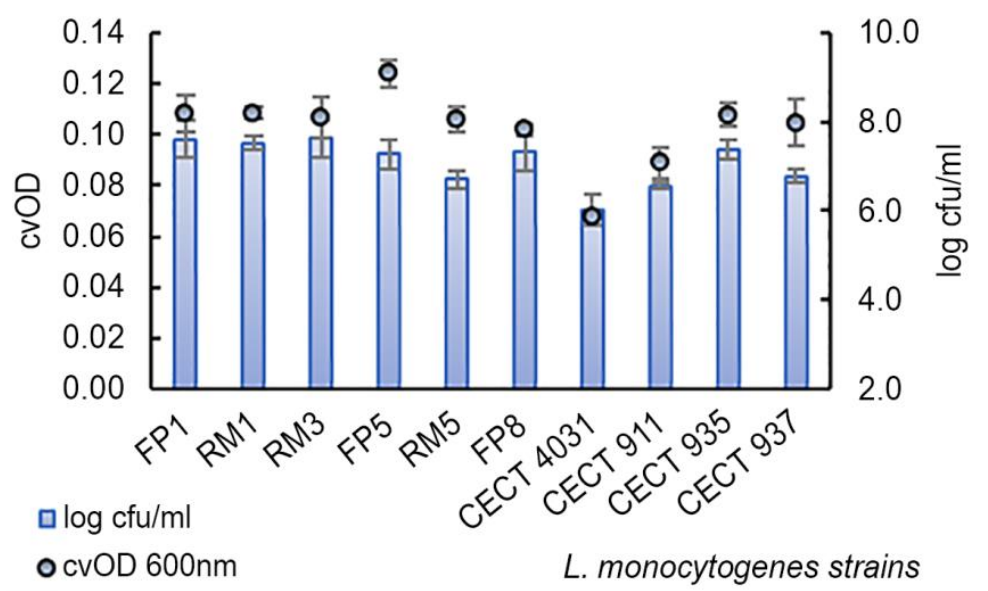

Figure 2. Average and standard deviation of $\log \mathrm{cfu} / \mathrm{mL}$ and cvOD of 5-day L. monocytogenes biofilms.

According to Stepanović et al. [40] classification, all the strains $(n=10)$ revealed a weak biofilm-forming ability. Similar results were obtained by Meloni et al. [41] when studying L. monocytogenes isolates from fermented sausage processing plants: $65 \%$ of all isolates were weak biofilm producers. However, in our work, the assessed strains exhibited significantly different degrees of biofilm-forming ability based on cvOD values $(p=0.0066)$, and VCC results did not reflect the same biofilm-forming ability classes as those obtained using cvOD values. Considering VCC values, all the strains, except L. monocytogenes FP1 and RM3 isolates, revealed lower values than L. monocytogenes CECT 935, which exhibited $7.4 \pm 0.2 \log \mathrm{cfu} / \mathrm{mL}$. On the other hand, when considering cvOD values, L. monocytogenes FP1, RM1, and FP6 isolates exhibited higher cvOD values than reference L. monocytogenes CECT 935 (0.1078 \pm 0.005$)$. Considering cvOD and VCC values, L. monocytogenes CECT 4031 revealed the lowest values for both parameters at $30^{\circ} \mathrm{C}$. The obtained difference between these two parameters is due to the nature of each method of determination. While cvOD measures the turbidity of a suspension and quantifies total biomass (viable and non-viable cells, but also extracellular matrix components), VCC only considers live cells [42]. Taking into account the selected methods to analyze biofilm formation-VCC $(\log \mathrm{cfu} / \mathrm{mL})$ and cvOD, Pearson's correlation analysis was performed. According to Pearson's correlation coefficient $(\rho=0.7749, p=0.009)$, there is a positive and strong correlation between both parameters, which indicates that both methods present a good relationship, being reliable to quantifying L. monocytogenes biofilm formation, complementing each other.

When relating the biofilm-forming ability using cvOD values with the assessed L. monocytogenes serogroups, no significant differences were found $(p=0.526)$ and the same happened for VCC values $(p=0.929)$ (Table 3).

Table 3. Biofilm-forming ability of L. monocytogenes strains according to the respective serogroups.

\begin{tabular}{cccc}
\hline L. monocytogenes Serogroup & $\boldsymbol{n}$ & Log cfu/mL (Mean \pm SD) & $\begin{array}{c}\text { cvOD } \\
\text { (Mean } \pm \text { SD) }\end{array}$ \\
\hline IIa & 4 & $7.2 \pm 0.8$ & $0.096 \pm 0.019$ \\
IIb & 2 & $7.0 \pm 0.4$ & $0.114 \pm 0.002$ \\
IIc & 2 & $7.0 \pm 0.7$ & $0.099 \pm 0.003$ \\
IVb & 2 & $7.1 \pm 0.5$ & $0.107 \pm 0.001$ \\
\hline
\end{tabular}


Similar results were obtained by Di Bonaventura et al. [43] when studying the association of phylogeny and biofilm production. Nevertheless, this study's results counteract the ones obtained by Meloni et al. [41], in which serotypes $1 / 2 a, 1 / 2 b$ and $4 b$ isolates presented a higher adherence when compared to serotype $1 / 2 \mathrm{c}$ isolates.

Other authors have shown that L. monocytogenes strains from different sources and serogroups are able to produce biofilms on a variety of surfaces, depending on the strain, surface and culture conditions $[13,44]$. Previous works reported that L. monocytogenes strains varied significantly in their ability to produce biofilm, but no trends could be observed when isolates' serotype and source were compared $[3,40]$. It is important to highlight that since there is a link between virulence and L. monocytogenes serotype, a continuous discussion relating biofilm formation and serotypes goes on, in order to determine whether biofilm formation is related to disease incidence [1,14].

For further testing, five L. monocytogenes strains (RM1, RM3, RM5, CECT 4031, and CECT 935) were selected based on serogrouping and biofilm formation parameters data analyses.

\subsection{Biocides Activity Testing Assay}

\subsubsection{Activity towards L. monocytogenes Planktonic Suspension}

The effect of food-grade commercial sanitizers, including an oxidizing compound (OxC), a quaternary ammonium compound $(\mathrm{QaC})$ and an ethanol-based compound (EthC) on the selected five L. monocytogenes strains was assessed. Tested concentrations were selected based on the manufacturer's recommendation for use in food contact surfaces. The manufacturer's recommended concentrations for $\mathrm{OxC}$ and EthC were found to be equally effective in inactivating the five tested strains in planktonic suspension, although this was not observed for QaC.

L. monocytogenes planktonic cells were inactivated by $50 \mathrm{ppm}$ or more (100 and $150 \mathrm{ppm}$ ) of OxC. Norwood and Gilmour [45] reported that a $30 \mathrm{sec}$ exposure to $10 \mathrm{ppm}$ free chlorine was enough to completely eliminate planktonic L. monocytogenes culture.

L. monocytogenes strains were exposed to increasing concentrations of EthC (50\%, 70\%, and 100\%) that seemed to be effective in inactivating planktonic cells. Similar results were obtained by Aarnisalo et al. [46].

L. monocytogenes planktonic forms enumeration after QaC treatment was not possible to perform within the tested concentration range. Some authors have reported resistance to QaCs in L. monocytogenes strains [47-49] and active efflux pumps are considered the main mechanism for L. monocytogenes tolerance to QaCs [50]. Because it was not possible to determine L. monocytogenes susceptibility to QaC, benzalkonium chloride $(\mathrm{BaC})$ was used to evaluate L. monocytogenes planktonic cells susceptibility. Figure 3 presents the effects of $\mathrm{BaC}$ treatment on the five selected L. monocytogenes strains planktonic suspensions. As shown, all strains in the planktonic form presented different susceptibilities to BaC, being affected by different concentrations. Reference strains L. monocytogenes CECT 4031 and CECT 935 were the most susceptible, presenting more than $4-\log \mathrm{cfu} / \mathrm{mL}$ reduction when exposed to $0.8 \mathrm{ppm}$ of BaC. L. monocytogenes RM1, RM3 and RM5 strains were less susceptible, presenting 4-log cfu/mL reduction only for concentrations higher than 12.5 ppm for RM1 and RM5 and 20 ppm for RM3. To have an 8-log cfu/mL reduction, L. monocytogenes CECT 4031 and CECT 935 planktonic cells were exposed to 2 ppm of BaC. The same was observed when RM1 and RM5 and RM3 were subjected to 25 ppm and 150 ppm, respectively. In line with our results, Nocker et al. [51] reported that the exposure of L. monocytogenes strains to $\mathrm{BaC}$ concentrations higher than $30 \mathrm{ppm}$ for 30 min was able to reduce bacterial colonies as measured by plate counts. 

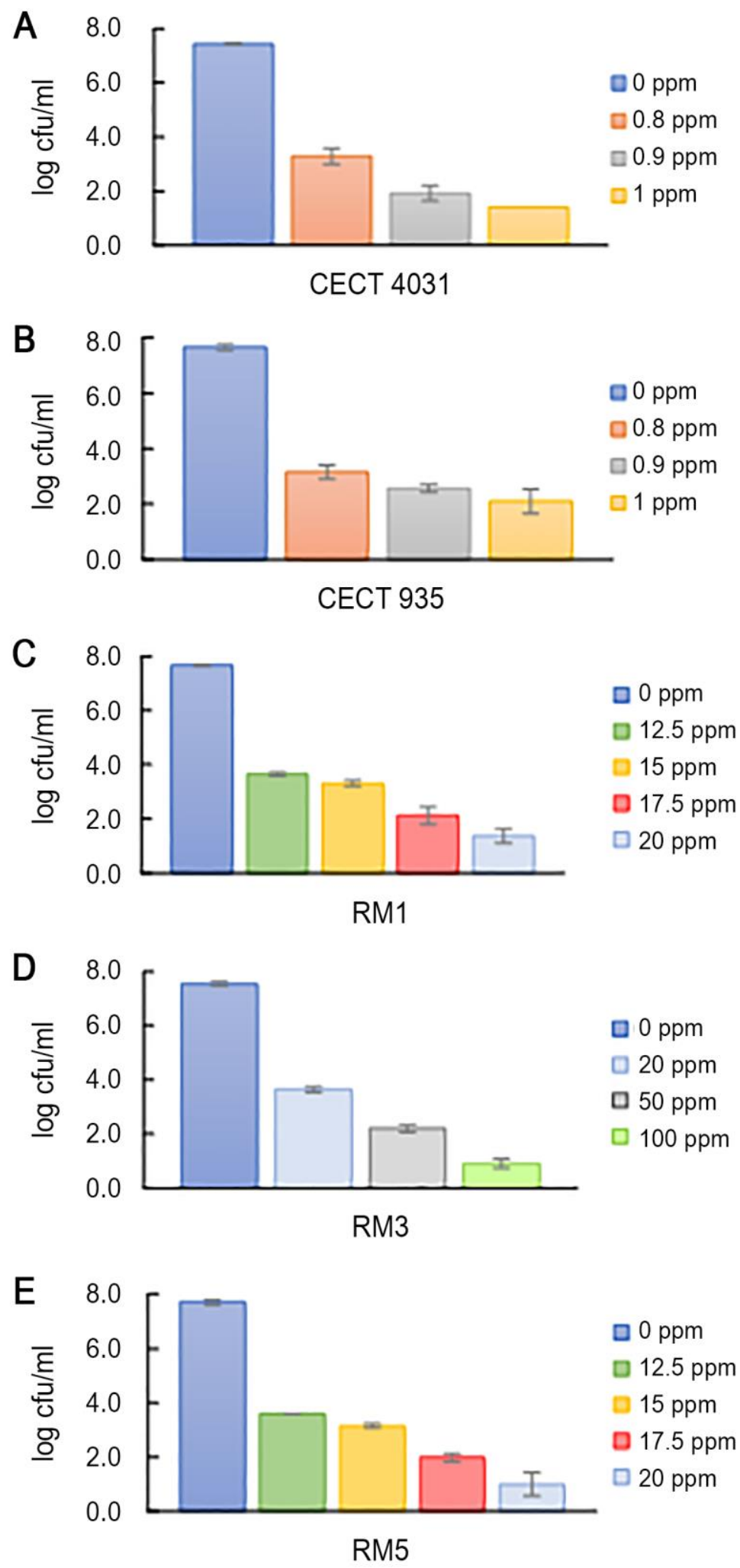

Figure 3. Viable cell counts average and standard deviation (error bars) of the tested planktonic L. monocytogenes strains after treatment with BaC. (A) L. monocytogenes CECT 4031; (B) L. monocytogenes CECT 935; (C) L. monocytogenes RM1; (D) L. monocytogenes RM3; (E) L. monocytogenes RM5. 


\subsubsection{Activity towards L. monocytogenes 5-day-old Biofilms}

The biocide activity testing assay on biofilms was based on the enumeration of viable cells. The three commercial compounds were tested on 5-day-old biofilms according to the manufacturer's recommended concentrations. As was observed for L. monocytogenes planktonic cells, both OxC and EthC tested concentrations, which were within the manufacturer's recommended concentrations, were able to eliminate biofilms of all the tested isolates in $5 \mathrm{~min}$ at $20^{\circ} \mathrm{C}$. In fact, it was reported that 200 ppm of sodium hypochlorite, an OxC, is enough to eliminate at least $20 \%$ of L. monocytogenes biofilms [3,45]. In contrast, after QaC's treatment, no susceptibility to this biocide was observed. Figure 4 presents the effect on VCC after treatment with $\mathrm{QaC}$ on the selected L. monocytogenes 5-day-old biofilms.

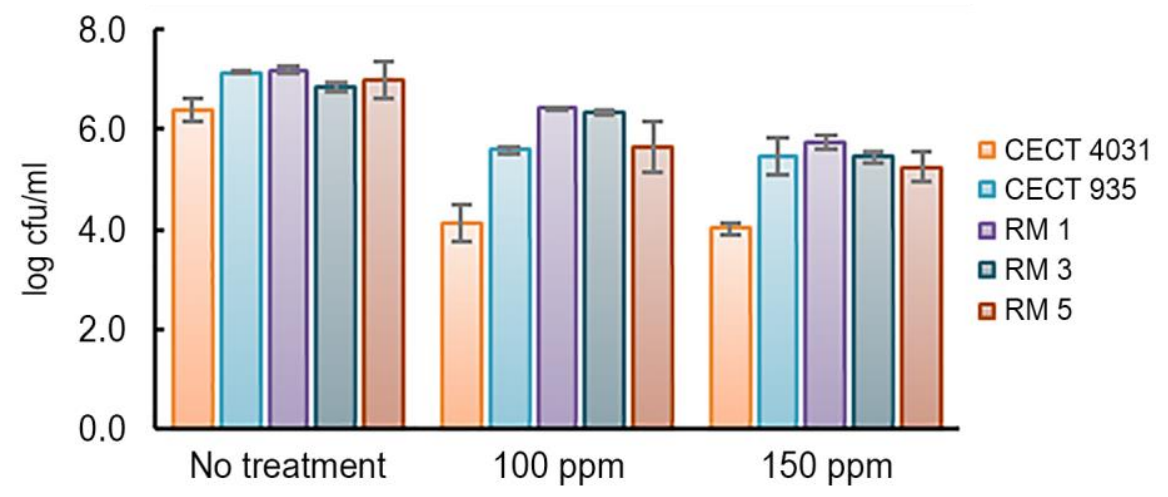

Figure 4. Average and standard deviation (error bars) of tested L. monocytogenes 5-day-old biofilms' VCC after QaC treatment.

In general, $\mathrm{QaC}$ was not effective in removing L. monocytogenes 5-day-old biofilms. As shown in Figure 4, when exposed to 150 ppm of QaC, L. monocytogenes CECT 4031 presented the highest reduction (from $6.4 \log \mathrm{cfu} / \mathrm{mL}$ to $4.0 \log \mathrm{cfu} / \mathrm{mL}$ ). The remaining L. monocytogenes strains presented approximately $1-\log \mathrm{cfu} / \mathrm{mL}$ reduction in VCC values. QaC resistance in L. monocytogenes biofilms has been reported [52,53]. Taking into account that this biocide is commonly used in food-related environments, these results are worrisome, as L. monocytogenes biofilms present a potential risk in food safety [54].

Figure 5 presents the tested concentration range of BaC's in L. monocytogenes 5-day-old biofilms. In general, L. monocytogenes 5-day-old biofilms' VCC were affected by different BaC concentrations, as happened for planktonic suspensions. While L. monocytogenes CECT 4031 was the most susceptible to BaC's treatment and also presented the lowest biofilm-forming ability, L. monocytogenes RM3 strain was the less susceptible, but presented the highest biofilm-forming ability based on VCC values. A 3- $\log \mathrm{cfu} / \mathrm{mL}$ reduction was observed for L. monocytogenes CECT 4031 after 5 min of exposure to $10 \mathrm{ppm}$ of $\mathrm{BaC}$. On the other hand, for a similar reduction on L. monocytogenes RM3 biofilm, 250 ppm of $\mathrm{BaC}$ were necessary. Comparing these results to those obtained for planktonic cells, it seems that L. monocytogenes biofilms are less susceptible to $\mathrm{BaC}^{\prime}$ s tested concentrations, since a higher BaC's concentration is needed to have an equivalent $\log \mathrm{cfu} / \mathrm{mL}$ reduction.

One example is L. monocytogenes RM3 isolate that in biofilm presented a 2-log cfu/mL reduction when exposed to $100 \mathrm{ppm}$ of $\mathrm{BaC}$ and a 3-log $\mathrm{cfu} / \mathrm{mL}$ reduction when exposed to $250 \mathrm{ppm}$, while the exposure to $150 \mathrm{ppm}$ of $\mathrm{BaC}$ in the planktonic form was enough to cause a $8-\log \mathrm{cfu} / \mathrm{mL}$ reduction. It has been previously discussed that in biofilm form, L. monocytogenes is more resistant to stress and sanitizing agents than planktonic cells [41,55]. Nakamura et al. [54], when assessing the sanitizing effect of $\mathrm{BaC}$ in L. monocytogenes planktonic cells and biofilms, reported that biofilm formation and tolerance to $\mathrm{BaC}$ might be related. Tolerance to $\mathrm{BaC}$ has also been reported by Piercey et al. [23] after testing $\mathrm{BaC}$ resistance and susceptibility based on the minimum inhibitory concentration, and by $\mathrm{Xu}$ et al. [24] after investigating phenotypic and genotypic tolerance to $\mathrm{BaC}$ based on susceptibility 
testing and molecular methods. Although in the last years several studies have focused on biofilm elimination, possible facilitating strategies are still unclear.
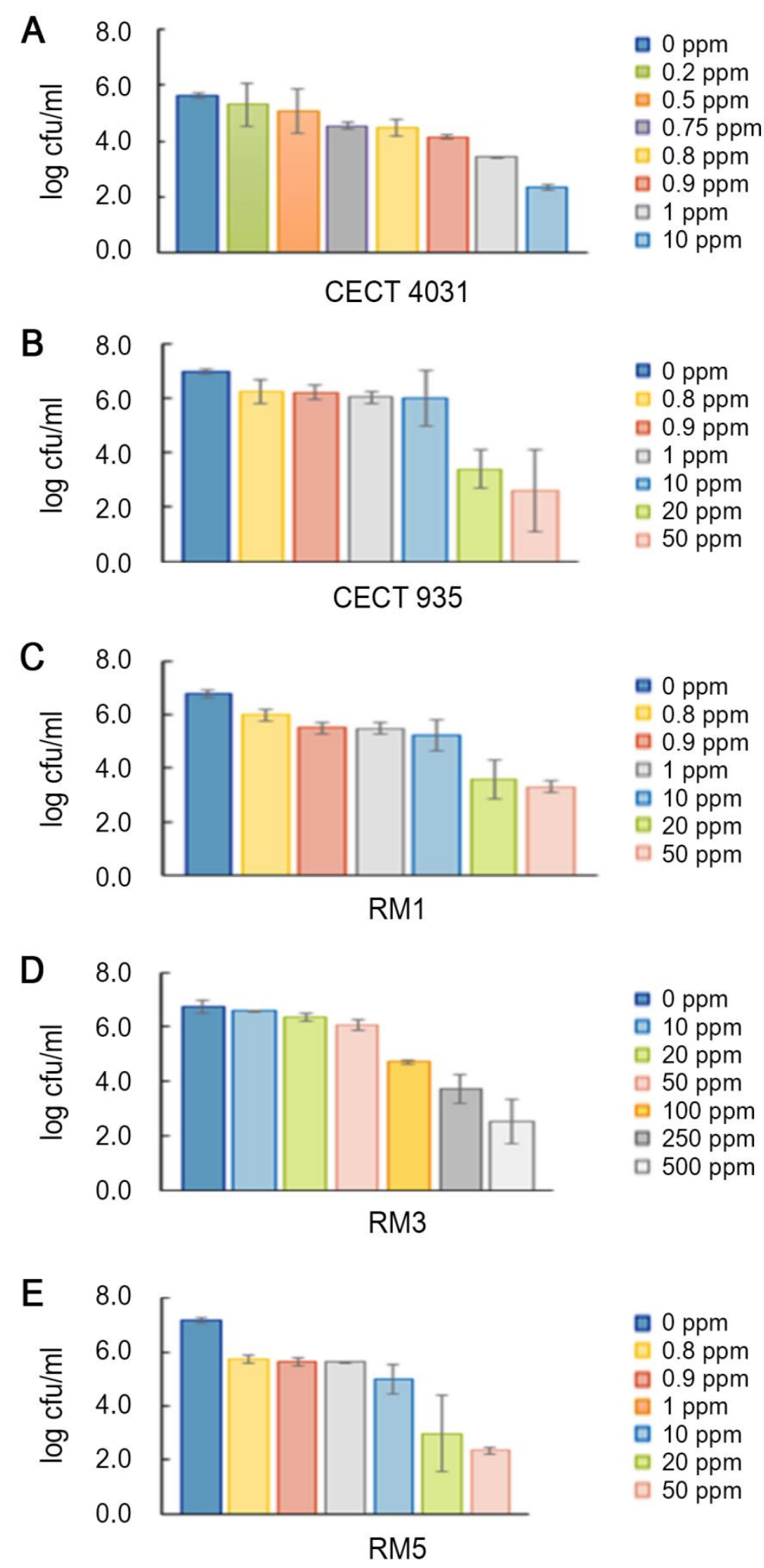

Figure 5. Viable cell counts average and standard deviation (error bars) of the tested L. monocytogenes 5-day-old biofilms after BaC treatment. (A) L. monocytogenes CECT 4031; (B) L. monocytogenes CECT 935; (C) L. monocytogenes RM1; (D) L. monocytogenes RM3; (E) L. monocytogenes RM5. 
To assess L. monocytogenes susceptibility to $\mathrm{QaC}$ and $\mathrm{BaC}, \mathrm{LD}_{90}$ values were calculated. Figure 6 presents $\mathrm{QaC} \mathrm{LD}_{90}$ values. These values ranged from 298.0 to $532.2 \mathrm{ppm}$, and were higher than the manufacturer's recommended concentrations to be used in food-related surfaces (maximum recommended concentration: $150 \mathrm{ppm})$.

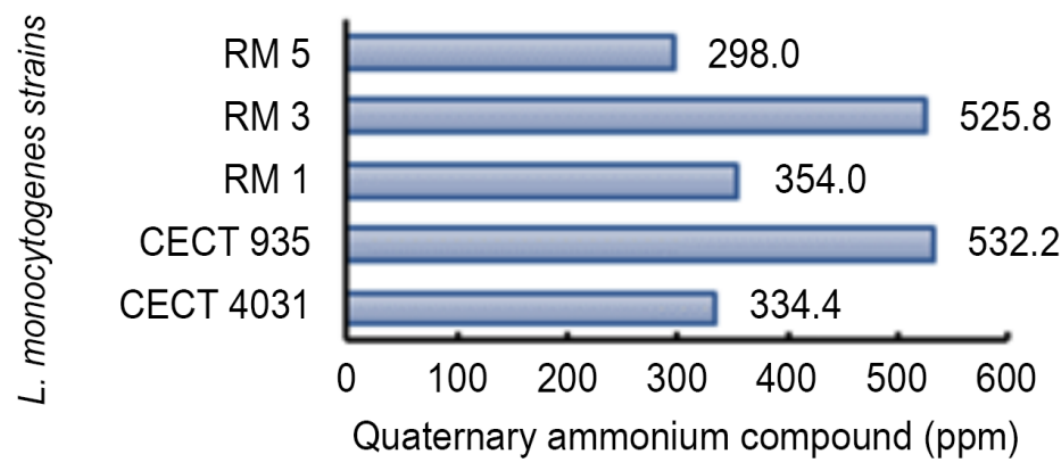

Figure 6. $\mathrm{LD}_{90}$ estimated values of L. monocytogenes tested strains in biofilm exposed to QaC.

This fact is relevant, because $\mathrm{QaC}$ is a commercial biocide that might be used in sublethal concentrations, which might induce L. monocytogenes resistance [46,56]. L. monocytogenes QaC resistance has been previously described, both for planktonic cells and biofilms [10,22,35].

$\mathrm{BaC}$ estimated $\mathrm{LD}_{90}$ values for L. monocytogenes tested strains (Figure 7) that ranged from 1.0 to $102.0 \mathrm{ppm}$ in the planktonic form and from 17.8 to $675.2 \mathrm{ppm}$ in biofilms, presenting significant differences $(p<0.0001)$.

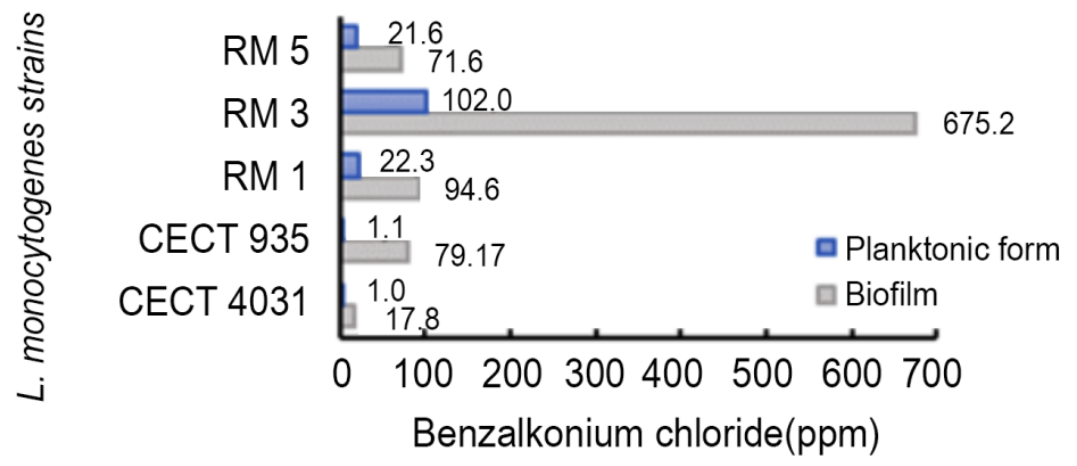

Figure 7. $\mathrm{LD}_{90}$ estimated values of L. monocytogenes tested strains in biofilm and in the planktonic form exposed to $\mathrm{BaC}$.

L. monocytogenes biofilms exhibited a reduced susceptibility to $\mathrm{BaC}$, compared to the planktonic forms. The biofilm structure may play an important role as the extracellular matrix acts like a barrier, preventing contact with antimicrobial agents [57,58]. In this study, the higher the biofilm-forming ability, the higher were the $\mathrm{LD}_{90}$ values for $\mathrm{QaC}$ and $\mathrm{BaC}$. This positive association of biofilm-forming ability and $\mathrm{LD}_{90}$ values was moderate, both for $\mathrm{QaC}$ and for BaC (Table 4).

Table 4. Pearson's correlation coefficients for biofilm-forming ability parameters and $\mathrm{LD}_{90}$ values for $\mathrm{QaC}$ and $\mathrm{BaC}$.

\begin{tabular}{ccc}
\hline LD $_{\mathbf{9 0}}$ Values & Log cfu/mL & QaC LD $_{\mathbf{9 0}}$ \\
\hline $\mathrm{QaC}$ & 0.652 & 1 \\
$\mathrm{BaC}$ & 0.554 & 0.607 \\
\hline
\end{tabular}

These results emphasize the importance of the cautious selection and use of sanitizers in food-producing premises. In fact, the equipment's sanitizing method should be re-assessed and 
validated in order to control L. monocytogenes contamination, as it might select isolates that are able to survive and adapt to the food processing environment [59], acting as potential contamination sources for RTE food produced in those surfaces. Taken together, biofilm-forming ability and LD 90 values underline the need to select different sanitizers, using rotating schemes, in order to prevent biocide resistance over time. Also, different strategies should be considered, other than the use of chemical biocides, as novel technologies, to control L. monocytogenes in the food production environment $[60,61]$.

\section{Materials and Methods}

\subsection{Characterization of L. monocytogenes Isolates Collection}

A collection of presumptive L. monocytogenes isolates $(n=20)$ was gathered from raw materials, intermediate, and final products, as well as industrial environment samples (food contact surfaces) of a RTE meat-based food producing industry (Table 1). This industry was located in Évora, Alentejo and produced pork meat delicatessens. L. monocytogenes isolates were collected during a 6-year period (2010-2015) as a result of routine microbiological sampling for industrial hygiene and food safety verification purposes, according to ISO 11290:1996 [62]. From a total of 76 collected samples, five raw materials, three intermediate products, nine finished RTE meat products and three food-contact surfaces were positive for L. monocytogenes. The strains were preserved in brain hearth infusion (BHI) broth (Scharlab, S.B., Barcelona, Spain) with 15\% glycerol (Merck KGaA, Darmstadt, Germany) at $-80{ }^{\circ} \mathrm{C}$ and revivified before use.

\subsection{L. monocytogenes Confirmation and Serogrouping by PCR}

Presumptive L. monocytogenes isolates $(n=20)$ were confirmed by PCR and serogrouped using a multiplex PCR and an additional PCR based on the amplification of the flaA gene [27]. L. monocytogenes confirmed isolates $(n=17)$ were selected for further genetic characterization.

\subsection{Pulsed-Field Electrophoresis Typing}

PFGE typing of the selected isolates was performed according to the PulseNet standardized procedure for L. monocytogenes [63]. Briefly, bacterial genomic DNA in 1.5\% agarose (SeaKem Gold Agarose, Cambrex, East Rutherford, NJ, USA) plugs was digested in separate reactions with 10U AscI (NZYTech, Lisbon, Portugal) for $2 \mathrm{~h}$ at $37{ }^{\circ} \mathrm{C}$, and with $50 \mathrm{U}$ ApaI (NZYTech) for $2 \mathrm{~h}$ at $25^{\circ} \mathrm{C}$. Electrophoresis of the resulting DNA fragments was performed in 1\% agarose gel (SeaKem Gold), with a lambda PFG ladder standard (New England Biolabs, Massachusetts, USA) in 0.5 X solution of Tris-borate-EDTA buffer (NZYTech) at $14{ }^{\circ} \mathrm{C}$, with $6 \mathrm{~V} / \mathrm{cm}$, initial pulsed time of $4.0 \mathrm{~s}$ and final pulsed time of $40 \mathrm{~s}$, included angle of $120^{\circ}$ over $19 \mathrm{~h}$ using a CHEF-Dr III System (Bio-Rad Laboratories, Hercules, CA, USA). Gels were stained with ethidium bromide (Sigma, St. Louis, MO, USA) and photographed under UV transillumination.

\subsection{Biofilm-Forming Ability Assay}

To assess biofilm formation, six L. monocytogenes strains were selected (RM1, RM3, RM5, FP1, FP5, and FP8) to have representatives from different serogroups and PFGE types. Also, four L. monocytogenes reference strains from the Spanish Type Culture Collection (CECT) were used: CECT 4031 (serogroup IIa), CECT 937 (serogroup IIb), CECT 911 (serogroup IIc), and CECT 935 (serogroup IVb). These strains present the same serogroups as the ones detected in this study isolates (Table 2), allowing for the comparison with existing studies.

The protocol proposed by Romanova et al. [51] was used with some modifications to obtain a 5-day L. monocytogenes mono-cultural biofilm. A single colony of each selected strain was inoculated in buffered peptone water (BPW) (Scharlab, S.B) and incubated for $16-18 \mathrm{~h}$ at $30{ }^{\circ} \mathrm{C}$. Optical density at $600 \mathrm{~nm}\left(\mathrm{OD}_{600 \mathrm{~nm}}\right)$ was assessed in Ultrospec 2000 (Pharmacia Biotech, Washington, WA, USA) to obtain a concentration of $8 \log \mathrm{cfu} / \mathrm{mL}$. For each strain, $4 \mu \mathrm{L}$ were transferred into three separate wells 
of polystyrene flat-bottomed microtiter plates (Normax, Marinha Grande, Portugal) filled with $200 \mu \mathrm{L}$ of BPW. Three wells were used as negative controls, with BPW alone. The plates were lidded and statically incubated at $30^{\circ} \mathrm{C}$ for 5 days. After this, the solution was removed from the wells that were rinsed once with sterile distilled water to remove loosely associated bacteria and the attached biofilms were assessed by viable cells enumeration and crystal violet staining.

Considering both evaluation methods, this assay was performed in triplicate, with three replicates for each strain.

\subsubsection{Enumeration of Viable Cells in Biofilms}

The biofilm was detached from the well surface mechanically into $100 \mu \mathrm{L}$ of BPW using a mini cell scraper (VWR International, Monroeville, PA, USA). The microtiter plate was sonicated (Ultrasonic bath MXB14, Grant Instruments, Royston, England) for $5 \mathrm{~min}$ to detach and collect sessile cells. Then, $100 \mu \mathrm{L}$ of BPW were pipetted into each well. Serial 10-fold dilutions of the sample in BPW were prepared and $10 \mu \mathrm{L}$ were dropped onto the surface of a tryptone soy agar (TSA) (Scharlab, S.B) plate. After overnight incubation at $30^{\circ} \mathrm{C}$, colonies were enumerated in a stereoscopic magnifier (Nikon SMZ645, Tokyo, Japan).

\subsubsection{Biofilm Assessment by Crystal Violet Staining}

The microtiter plate was left air drying for $45 \mathrm{~min}$ in the laminar flow hood. Biofilm was stained by adding $220 \mu \mathrm{L}$ of $0.1 \%$ crystal violet (bioMérieux, France) solution to each well for $15 \mathrm{~min}$ at room temperature. After stain removal, the wells were washed three times with sterile distilled water and left air drying for $30 \mathrm{~min}$ in the laminar flow hood. Then, $220 \mu \mathrm{L}$ of detaining solution (ethanol: acetone 80:20 v/v) were added to each well $15 \mathrm{~min}$. The microtiter plate was then shaken (Ultrasonic bath MXB14, Grant Instruments, Royston, England) for 5 min and the crystal violet OD (cvOD) was measured in SpectraMax 340PC (Molecular Devices, Silicon Valley, San Jose, CA, USA). Each absorbance value was corrected by subtracting the average absorbance readings of the blank control wells. Adherence capability of the tested strains was based on the cvOD exhibited by bacterial biofilms, according to Stepanović et al. [40] classification. The cut-off cvOD (cvODc) was defined as three standard deviations above the negative control mean cvOD. Strains were classified as no biofilm producers ( $\mathrm{cvOD} \leq \mathrm{cvODc}$ ), weak biofilm producers ( $\mathrm{cvODc}<\mathrm{cvOD} \leq 2 \times \mathrm{cvODc}$ ), moderate biofilm producers $(2 \times \mathrm{cvODc}<\mathrm{cvOD} \leq 4 \times \mathrm{cvODc})$, and strong biofilm producers $(4 \times \mathrm{cvODc}<\mathrm{cvOD})$.

\subsection{Biocides Activity Testing Assay}

Based on serogrouping and biofilm formation parameters, L. monocytogenes strains RM1, RM3 and RM5 and L. monocytogenes reference strains CECT 4031 and CECT 935 were selected to be further assessed.

Biocides activity testing was performed according to European standard EN 1276:2009 [64], using the quantitative suspension test for bactericidal activity evaluation of chemical disinfectants used in food and industrial areas. To simulate clean conditions, in all tests, $0.03 \mathrm{~g} / \mathrm{L}$ of bovine serum albumin (Merck KGaA) was used as an interfering substance. Contact time $(5 \mathrm{~min})$ and temperature $\left(20^{\circ} \mathrm{C}\right)$ were established according to the obligatory test conditions specified in EN 1276:2009. For all strains, experimental conditions were previously validated. Biocide activity was assessed using Escherichia coli DSMZ 682, Pseudomonas aeruginosa ATCC 15442, Staphylococcus aureus CECT 239, and Enterococcus hirae ATCC 10541D-5, to validate dilution-neutralization, absence of lethal effect in test conditions, including neutralizer toxicity, and efficacy of neutralizing solutions.

Commonly used biocides in food contact surfaces and equipment sanitization in food-producing establishments were selected for further testing. Commercial sanitizers (HigiaBlue, Portugal) containing oxidizing compounds $(\mathrm{OxC})$, ethanol-based compounds $(\mathrm{EthC})$ and quaternary ammonium compounds $(\mathrm{QaC})$ were tested. Benzalkonium chloride (BaC; Merck KGaA) was also evaluated. Table 5 exhibits the tested concentrations for each biocide (diluted in hard water) and respective neutralizers. 
Table 5. Tested biocides, concentration range and neutralizers used in biocide activity testing assay (EN 1276:2009).

\begin{tabular}{|c|c|c|c|c|}
\hline Biocide & \multicolumn{3}{|c|}{ Tested Concentrations } & Neutralizer \\
\hline Oxidizing compound (OxC) & $50 \mathrm{ppm}$ & 100 ppm & 150 ppm & $\begin{array}{c}\text { Polysorbate } 80,30 \mathrm{~g} / \mathrm{L}+\text { lecithin, } 3 \mathrm{~g} / \mathrm{L}+\text { sodium } \\
\text { thiosulphate } 10 \mathrm{~g} / \mathrm{L}\end{array}$ \\
\hline $\begin{array}{l}\text { Quaternary ammonium } \\
\text { compound }(\mathrm{QaC})\end{array}$ & $50 \mathrm{ppm}$ & 100 ppm & 150 ppm & $\begin{array}{l}\text { Polysorbate } 80,30 \mathrm{~g} / \mathrm{L}+\text { sodium dodecyl sulphate, } \\
44 \mathrm{~g} / \mathrm{L}+\text { lecithin, } 3 \mathrm{~g} / \mathrm{L}\end{array}$ \\
\hline Ethanol-based compound (EthC) & $50 \%$ & $70 \%$ & $100 \%$ & $\begin{array}{c}\text { Polysorbate } 80,30 \mathrm{~g} / \mathrm{L}+\text { saponin, } 30 \mathrm{~g} / \mathrm{L}+\text { lecithin, } \\
\qquad 3 \mathrm{~g} / \mathrm{L}\end{array}$ \\
\hline \multirow{2}{*}{ Benzalkonium chloride $(\mathrm{BaC})$} & \multicolumn{2}{|c|}{ Planktonic cells } & Biofilm & \\
\hline & \multicolumn{2}{|c|}{$0.8-150 \mathrm{ppm}$} & $0.2-500 \mathrm{ppm}$ & $\begin{array}{l}\text { Polysorbate } 80,30 \mathrm{~g} / \mathrm{L}+\text { sodium dodecyl sulphate, } \\
4 \mathrm{~g} / \mathrm{L}+\text { lecithin, } 3 \mathrm{~g} / \mathrm{L}\end{array}$ \\
\hline
\end{tabular}

All measurements were performed in duplicate and all experiments were performed twice.

\subsubsection{Activity towards L. monocytogenes Planktonic Suspension}

L. monocytogenes strains were incubated in BHI agar (Scharlab, S.B.) at $37^{\circ} \mathrm{C}$ for $18 \mathrm{~h}$. Then, $10 \mathrm{~mL}$ of the bacterial suspension were prepared to have an $\mathrm{OD}_{600 \mathrm{~nm}}$ of $0.15-0.5$, corresponding to a concentration of approximately $1.5-5 \times 10^{8} \mathrm{cfu} / \mathrm{mL}$. To each tube containing $1 \mathrm{~mL}$ of interfering substance, $1 \mathrm{~mL}$ of the bacterial suspension was added, and the mixture was vortexed. After $2 \mathrm{~min}$, $8 \mathrm{~mL}$ of one of the desired biocide test concentration were added, incubating for $5 \mathrm{~min}$ at $20^{\circ} \mathrm{C}$. Then, $1 \mathrm{~mL}$ was collected and mixed with $1 \mathrm{~mL}$ of hard water and $8 \mathrm{~mL}$ of the appropriate neutralizer. After neutralization $\left(5 \mathrm{~min}\right.$ at $\left.20^{\circ} \mathrm{C}\right), 1 \mathrm{~mL}$ was incorporated in TSA (Scharlab, S.B.) in duplicate. After overnight incubation at $37^{\circ} \mathrm{C}$, colonies were enumerated.

\subsubsection{Activity towards L. monocytogenes 5-day-old Biofilms}

For the biocide activity testing on L. monocytogenes 5-day-old biofilms, to each well containing the biofilm, $20 \mu \mathrm{L}$ of interfering substance and $20 \mu \mathrm{L}$ of tryptone salt solution (Scharlab, S.B.) were added. After $2 \mathrm{~min}, 160 \mu \mathrm{L}$ of one of the biocide test concentrations was added and incubated for $5 \mathrm{~min}$ at $20{ }^{\circ} \mathrm{C}$. After medium removal, the wells were washed with $40 \mu \mathrm{L}$ of hard water and $160 \mu \mathrm{L}$ of the appropriate neutralizer. After neutralization $\left(5 \mathrm{~min}\right.$ at $\left.20^{\circ} \mathrm{C}\right)$, the medium was removed and the wells were washed with sterile distilled water, which was also removed. The biofilm quantification was performed according to the procedure described in Section 3.4.1. for biofilm detachment, dilution and colony enumeration.

$\mathrm{LD}_{90}$ was then calculated for both planktonic and biofilm assays in order to determine the biocide concentration that reduced $90 \%$ of VCC.

\subsection{Data Analyses}

All quantitative data are presented as mean values with standard deviation (SD) from three independent experiments. Using BioNumerics software package version 6.10 (Applied Maths, Sint-Martens-Latem, Belgium), a dendrogram was constructed based on PFGE patterns of the 17 L. monocytogenes strains, with an optimization setting of $1.5 \%$ and a band-position tolerance of $1.5 \%$ for AscI and ApaI restriction. Cluster analysis was performed using the unweighted pair group method (UPGMA) with arithmetic averages and band-based Dice correlation coefficient.

To assess L. monocytogenes biofilm formation parameters, Pearson's correlation analyses were used to evaluate the interdependency of $\mathrm{cvOD}$ and VCC. To relate biofilm formation parameters and L. monocytogenes serogroups, one-way analysis of variance (ANOVA) followed by Tukey's test were performed.

To evaluate the susceptibility of selected L. monocytogenes strains to biocides, $\mathrm{LD}_{90}$ values were obtained by adjusting experimental data of mortality obtained in biocide testing assays to a polynomial equation or to a linear regression adjusted to a scatter plot of mortality versus biocide concentration in MS Excel 2016 software (Microsoft Corporation, Redmond, USA). Two-way ANOVA was used to 
compare $\mathrm{BaC} \mathrm{LD}_{90}$ values in planktonic and biofilm forms. To compare L. monocytogenes biofilms $\mathrm{QaC}$ $\mathrm{LD}_{90}$ values and also BaC $\mathrm{LD}_{90}$ values, one-way ANOVA followed by Tukey's test were performed. Pearson's correlation coefficient was also used to relate biofilm formation parameters and QaC and $\mathrm{BaC} \mathrm{LD}_{90}$. When $p<0.05$, a statistically significant difference was considered.

\section{Conclusions}

Overall, this study provided an assessment of L. monocytogenes isolates from a RTE meat-based food industry, using phenotypic and genetic characterization. The use of molecular and subtyping techniques is an important tool to understand the routes and sources of contamination. Our results reveal that L. monocytogenes contamination of finished products seems to be related to food-contact surfaces, but also to raw materials. Moreover, some of the obtained pulsotypes revealed high homology $(>90 \%)$ but were not temporally matched, being collected with months of interval. These results might point out to a common source of contamination and are consistent with the hypothesis that there are stable clonal groups of L. monocytogenes, which persist over time, in foods and food-related environments.

All of the studied L. monocytogenes strains demonstrated biofilm-forming ability at $30^{\circ} \mathrm{C}$, revealing to be weak biofilm producers. Strains in biofilms were not susceptible to one of the used commercial sanitizers in the industrial premises, $\mathrm{QaC}$, within the recommended concentration range. Similar results were obtained when testing a pure substance biocide, benzalkonium chloride $(\mathrm{BaC})$ in L. monocytogenes biofilms. In contrast, L. monocytogenes planktonic forms were susceptible to $\mathrm{BaC}$ tested concentrations. A positive association was found between biofilm formation parameters and $\mathrm{LD}_{90}$ values for $\mathrm{QaC}$ and $\mathrm{BaC}$.

Taken together, our results suggest that preventive measures need improvement in the assessed food industry. It also reinforces the necessity of an appropriate selection and application of biocides in food premises, to prevent L. monocytogenes biofilm formation and biocide resistance development over time.

Author Contributions: Conceptualization, A.R.H.; methodology, J.C.A., C.d.S.A., A.L.J., software, J.C.A., validation, A.R.H., A.L.J., formal analysis, J.C.A., A.R.H.; investigation, J.C.A., C.d.S.A., A.L.J.; resources, A.S.B., A.L.J.; data curation, A.R.H., A.L.J.; writing-original draft preparation, J.C.A.; writing-review and editing, A.S.B., A.R.H.; supervision, A.S.B., A.R.H.; project administration, A.R.H.; funding acquisition, A.R.H.; All authors have read and agreed to the published version of the manuscript.

Funding: This research was supported by Project UIDP/CVT/00276/2020 (funded by FCT).

Acknowledgments: The authors gratefully acknowledge Maria Helena Fernandes, Maria José Fernandes and Maria Paula Silva for the technical support and Carla Carneiro for the discussion time. We acknowledge the logistic support of CIISA - Centro de Investigação Interdisciplinar em Sanidade Animal, Faculdade de Medicina Veterinária, Universidade de Lisboa, Avenida da Universidade Técnica, 1300-477 Lisboa, Portugal.

Conflicts of Interest: The authors declare no conflict of interest.

\section{References}

1. Orsi, R.H.; den Bakker, H.C.; Wiedmann, M. Listeria monocytogenes lineages: Genomics, evolution, ecology, and phenotypic characteristics. Int. J. Med. Microbiol. 2011, 301, 79-96. [CrossRef]

2. Gandhi, M.; Chikindas, M.L. Listeria: A foodborne pathogen that knows how to survive. Int. J. Food Microbiol. 2007, 113, 1-15. [CrossRef]

3. Russo, P.; Hadjilouka, A.; Beneduce, L.; Capozzi, V.; Paramithiotis, S.; Drosinos, E.; Spano, G. Effect of different conditions on Listeria monocytogenes biofilm formation and removal. Czech J. Food Sci. 2018, 36, 208-214. [CrossRef]

4. Paudyal, R.; Barnes, R.H.; Karatzas, K.A.G. A novel approach in acidic disinfection through inhibition of acid resistance mechanisms; Maleic acid-mediated inhibition of glutamate decarboxylase activity enhances acid sensitivity of Listeria monocytogenes. Food Microbiol. 2018, 69, 96-104. [CrossRef] [PubMed]

5. Bonsaglia, E.C.R.; Silva, N.C.C.; Fernandes, J.A.; Araújo Junior, J.P.; Tsunemi, M.H.; Rall, V.L.M. Production of biofilm by Listeria monocytogenes in different materials and temperatures. Food Control. 2014, 35, 386-391. [CrossRef] 
6. Bolocan, A.S.; Nicolau, A.I.; Alvarez-Ordóñez, A.; Borda, D.; Oniciuc, E.A.; Stessl, B.; Gurgu, L.; Wagner, M.; Jordan, K. Dynamics of Listeria monocytogenes colonisation in a newly-opened meat processing facility. Meat Sci. 2016, 113, 26-34. [CrossRef] [PubMed]

7. Amajoud, N.; Leclercq, A.; Soriano, J.M.; Bracq-Dieye, H.; Maadoudi, M.E.; Senhaji, N.S.; Kounnoun, A.; Moura, A.; Lecuit, M.; Abrini, J. Prevalence of Listeria spp. and characterization of Listeria monocytogenes isolated from food products in Tetouan, Morocco. Food Control. 2018, 84, 436-441. [CrossRef]

8. Henriques, A.R.; Fraqueza, M.J. Listeria monocytogenes and ready-to-eat meat-based food products: Incidence and control. In Listeria monocytogenes: Incidence, Growth Behavior and Control, 1st ed.; Viccario, T., Ed.; Nova Science Publishers Inc.: New York, NY, USA, 2015; pp. 71-103.

9. Olszewska, M.A.; Zhao, T.; Doyle, M.P. Inactivation and induction of sublethal injury of Listeria monocytogenes in biofilm treated with various sanitizers. Food Control. 2016, 70, 371-379. [CrossRef]

10. Ortiz, S.; López, V.; Martínez-Suárez, J.V. Control of Listeria monocytogenes contamination in an Iberian pork processing plant and selection of benzalkonium chloride-resistant strains. Food Microbiol. 2014, 39, 81-88. [CrossRef]

11. Ibusquiza, P.S.; Herrera, J.J.; Vázquez-Sánchez, D.; Parada, A.; Cabo, M.L. A new and efficient method to obtain benzalkonium chloride adapted cells of Listeria monocytogenes. J. Microbiol. Methods 2012, 91, 57-61. [CrossRef]

12. Nilsson, R.E.; Ross, T.; Bowman, J.P. Variability in biofilm production by Listeria monocytogenes correlated to strain origin and growth conditions. Int. J. Food Microbiol. 2011, 150, 14-24. [CrossRef] [PubMed]

13. Papaioannou, E.; Giaouris, E.D.; Berillis, P.; Boziaris, I.S. Dynamics of biofilm formation by Listeria monocytogenes on stainless steel under mono-species and mixed-culture simulated fish processing conditions and chemical disinfection challenges. Int. J. Food Microbiol. 2018, 267, 9-19. [CrossRef] [PubMed]

14. Wang, W.; Zhou, X.; Suo, Y.; Deng, X.; Cheng, M.; Shi, C.; Shi, X. Prevalence, serotype diversity, biofilm-forming ability and eradication of Listeria monocytogenes isolated from diverse foods in Shanghai, China. Food Control. 2017, 73, 1068-1073. [CrossRef]

15. Doijad, S.P.; Barbuddhe, S.B.; Garg, S.; Poharkar, K.V.; Kalorey, D.R.; Kurkure, N.V.; Rawool, D.B.; Chakraborty, T. Biofilm-forming abilities of Listeria monocytogenes serotypes isolated from different sources. PLoS ONE 2015, 10, e0137046. [CrossRef]

16. Borucki, M.K.; Peppin, J.D.; White, D.; Loge, F.; Call, D.R. Variation in biofilm formation among strains of Listeria monocytogenes. Appl. Environ. Microbiol. 2003, 69, 7336-7342. [CrossRef] [PubMed]

17. Mazaheri, T.; Ripolles-Avila, C.; Hascoët, A.S.; Rodríguez-Jerez, J.J. Effect of an enzymatic treatment on the removal of mature Listeria monocytogenes biofilms: A quantitative and qualitative study. Food Control. 2020, 114, 107266. [CrossRef]

18. Sadekuzzaman, M.; Mizan, M.F.R.; Kim, H.S.; Yang, S.; Ha, S.D. Activity of thyme and tea tree essential oils against selected foodborne pathogens in biofilms on abiotic surfaces. LWT 2018, 89, 134-139. [CrossRef]

19. Puga, C.H.; Orgaz, B.; SanJose, C. Listeria monocytogenes impact on mature or old Pseudomonas fluorescens biofilms during growth at 4 and $20^{\circ} \mathrm{C}$. Front. Microbiol. 2016, 7, 134. [CrossRef]

20. Tamburro, M.; Ripabelli, G.; Vitullo, M.; Dallman, T.J.; Pontello, M.; Amar, C.F.; Sammarco, M.L. Gene expression in Listeria monocytogenes exposed to sublethal concentration of benzalkonium chloride. Comp. Immunol. Microbiol. Infect. Dis. 2015, 40, 31-39. [CrossRef]

21. Henriques, A.R.; Fraqueza, M.J. Biofilm-forming ability and biocide susceptibility of Listeria monocytogenes strains isolated from the ready-to-eat meat-based food products food chain. LWT 2017, 81, 180-187. [CrossRef]

22. Kocot, A.M.; Olszewska, M.A. Biofilm formation and microscopic analysis of biofilms formed by Listeria monocytogenes in a food processing context. LWT 2017, 84, 47-57. [CrossRef]

23. Piercey, M.J.; Elis, T.C.; Macintosh, A.J.; Truelstrup, H.L. Variations in biofilm formation, desiccation resistance and benzalkonium chloride susceptibility among Listeria monocytogenes strains isolated in Canada. Int. J. Food Microbiol. 2017, 257, 254-261. [CrossRef] [PubMed]

24. Xu, D.; Li, Y.; Zahid, M.S.; Yamasaki, S.; Shi, L.; Li, J.R.; Yan, H. Benzalkonium chloride and heavy-metal tolerance in Listeria monocytogenes from retail foods. Int. J. Food Microbiol. 2014, 190, 24-30. [CrossRef] [PubMed]

25. Barroso, I.; Maia, V.; Cabrita, P.; Martínez-Suárez, J.V.; Brito, L. The benzalkonium chloride resistant or sensitive phenotype of Listeria monocytogenes planktonic cells did not dictate the susceptibility of its biofilm counterparts. Food Res. Int. 2019, 123, 373-382. [CrossRef] [PubMed] 
26. Mena, C.; Almeida, G.; Sá-Carneiro, L.; Teixeira, P.; Hogg, T.; Gibbs, P.A. Incidence of Listeria monocytogenes in different food products commercialized in Portugal. Food Microbiol. 2004, 21, 213-216. [CrossRef]

27. Kérouanton, A.; Marault, M.; Petit, L.; Grout, J.; Dao, T.T.; Brisabois, A. Evaluation of a multiplex PCR assay as an alternative method for Listeria monocytogenes serotyping. J. Microbiol. Methods 2010, 80, 134-137. [CrossRef]

28. Lotfollahi, L.; Chaharbalesh, A.; Ahangarzadeh, R.M.; Hasani, A. Prevalence, antimicrobial susceptibility and multiplex PCR-serotyping of Listeria monocytogenes isolated from humans, foods and livestock in Iran. Microb. Pathog. 2017, 107, 425-429. [CrossRef]

29. Montero, D.; Bodero, M.; Riveros, G.; Lapierre, L.; Gaggero, A.; Vidal, R.M.; Vidal, M. Molecular epidemiology and genetic diversity of Listeria monocytogenes isolates from a wide variety of ready-to-eat foods and their relationship to clinical strains from listeriosis outbreaks in Chile. Front. Microbiol. 2015, 6, 384. [CrossRef]

30. Sheng, J.; Tao, T.; Zhu, X.; Bie, X.; Lv, F.; Zhao, H.; Lu, Z. A multiplex PCR detection method for milk based on novel primers specific for Listeria monocytogenes 1/2a serotype. Food Control. 2018, 86, 183-190. [CrossRef]

31. Rodríguez-López, P.; Ibusquiza, P.S.; Mosquera-Fernández, M.; López-Cabo, M. Listeria monocytogenescarrying consortia in food industry. Composition, subtyping and numerical characterisation of mono-species biofilm dynamics on stainless steel. Int. J. Food Microbiol. 2015, 206, 84-95. [CrossRef]

32. Torresi, M.; Acciari, V.A.; Zennaro, G.; Prencipe, V.; Migliorati, G. Comparison of Multiple-locus variable number tandem repeat analysis and pulsed-field gel electrophoresis in molecular subtyping of Listeria monocytogenes isolates from Italian cheese. Vet. Ital. 2015, 51, 191-198.

33. Nyarko, E.B.; Donnelly, C.W. Listeria monocytogenes: Strain heterogeneity, methods, and challenges of subtyping. J. Food Sci. 2015, 80, 2868-2878. [CrossRef] [PubMed]

34. Kurpas, M.; Wieczorek, K.; Osek, J. Ready-to-eat meat products as a source of Listeria monocytogenes. J. Vet. Res. 2018, 62, 49-55. [CrossRef] [PubMed]

35. Buchanan, R.L.; Gorris, L.G.M.; Hayman, M.M.; Jackson, T.C.; Whiting, R.C. A review of Listeria monocytogenes: An update on outbreaks, virulence, dose-response, ecology, and risk assessments. Food Control. 2017, 75, 1-13. [CrossRef]

36. Malley, T.J.V.; Butts, J.; Wiedmann, M. Seek and destroy process: Listeria monocytogenes process controls in the ready-to-eat meat and poultry industry. J. Food Prot. 2015, 78, 436-445. [CrossRef]

37. Doumith, M.; Buchrieser, C.; Glaser, P.; Jacquet, C.; Martin, P. Differentiation of the major Listeria monocytogenes serovars by multiplex PCR. J. Clin. Microbiol. 2004, 42, 3819-3822. [CrossRef]

38. Datta, A.R.; Burall, L.S. Serotype to genotype: The changing landscape of listeriosis outbreak investigations. Food Microbiol. 2018, 75, 18-27. [CrossRef]

39. Su, X.; Zhang, J.; Shi, W.; Yang, X.; Li, Y.; Pan, H.; Kuang, D.; Xu, D.; Shi, X.; Meng, J. Molecular characterization and antimicrobial susceptibility of Listeria monocytogenes isolated from foods and humans. Food Control. 2016, 70, 96-102. [CrossRef]

40. Stepanović, S.; Cirković, I.; Ranin, L.; Svabić-Vlahović, M. Biofilm formation by Salmonella spp. and Listeria monocytogenes on plastic surface. Lett. Appl. Microbiol. 2004, 38, 428-432. [CrossRef]

41. Meloni, D.; Consolati, S.G.; Mazza, R.; Mureddu, A.; Fois, F.; Piras, F.; Mazzette, R. Presence and molecular characterization of the major serovars of Listeria monocytogenes in ten Sardinian fermented sausage processing plants. Meat Sci. 2014, 97, 443-450. [CrossRef]

42. Kwasny, S.M.; Opperman, T.J. Static biofilm cultures of gram-positive pathogens grown in a microtiter format used for anti-biofilm drug discovery. Curr. Protoc. Pharmacol. 2010, 13, 8-23. [CrossRef] [PubMed]

43. Di Bonaventura, G.; Piccolomini, R.; Paludi, D.; D’Orio, V.; Vergara, A.; Conter, M.; Ianieri, A. Influence of temperature on biofilm formation by Listeria monocytogenes on various food-contact surfaces: Relationship with motility and cell surface hydrophobicity. J. Appl. Microbiol. 2008, 104, 1552-1561. [CrossRef] [PubMed]

44. Reis-Teixeira, F.B.; Alves, V.F.; Martinis, E.C.P. Growth, viability and architecture of biofilms of Listeria monocytogenes formed on abiotic surfaces. Braz. J. Microbiol. 2017, 48, 587-591. [CrossRef] [PubMed]

45. Norwood, D.E.; Gilmour, A. The growth and resistance to sodium hypochlorite of Listeria monocytogenes in a steady-state multispecies biofilm. J. Appl. Microbiol. 2000, 88, 512-520. [CrossRef]

46. Aarnisalo, K.; Lundén, J.; Korkeala, H.; Wirtanen, G. Susceptibility of Listeria monocytogenes strains to disinfectants and chlorinated alkaline cleaners at cold temperatures. LWT 2007, 40, 1041-1048. [CrossRef]

47. Ibusquiza, P.S.; Herrera, J.J.R.; Cabo, M.L. Resistance to benzalkonium chloride, peracetic acid and nisin during formation of mature biofilms by Listeria monocytogenes. Food Microbiol. 2011, 28, 418-425. [CrossRef] 
48. Sidhu, M.S.; Heir, E.; Sorum, H.; Holck, A. Genetic linkage between resistance to quaternary ammonium compounds and $\beta$-Lactam antibiotics in food-related Staphylococcus spp. Microb. Drug Res. 2001, 7, 363-371. [CrossRef] [PubMed]

49. Romanova, N.A.; Gawande, P.V.; Brovko, L.Y.; Griffiths, M.W. Rapid methods to assess sanitizing efficacy of benzalkonium chloride to Listeria monocytogenes biofilms. J. Microbiol. Methods 2007, 71, 231-237. [CrossRef]

50. Rodríguez-López, P.; Rodríguez-Herrera, J.J.; Vázquez-Shánchez, D.; López-Cabo, M. Current knowledge on Listeria monocytogenes biofilms in food-related environments: Incidence, resistance to biocides, ecology and biocontrol. Foods 2018, 7, 85. [CrossRef]

51. Nocker, A.; Sossa, K.E.; Camper, A.K. Molecular monitoring of disinfection efficacy using propidium monoazide in combination with quantitative PCR. J. Microbiol. Methods 2007, 70, 252-260. [CrossRef]

52. Pan, Y.; Breidt, F.; Kathariou, S. Resistance of Listeria monocytogenes biofilms to sanitizing agents in a simulated food processing environment. Appl. Environ. Microbiol. 2006, 72, 7711-7717. [CrossRef] [PubMed]

53. Katharios-Lanwermeyer, S.; Rakic-Martinez, M.; Elhanafi, D.; Ratani, S.; Tiedje, J.M.; Kathariou, S. Coselection of cadmium and benzalkonium chloride resistance in conjugative transfers from nonpathogenic Listeria spp. to other listeriae. Appl. Environ. Microbiol. 2012, 78, 7549-7556. [CrossRef]

54. Nakamura, H.; Takakura, K.; Sone, Y.; Itano, Y.; Nishikawa, Y. Biofilm formation and resistance to benzalkonium chloride in Listeria monocytogenes isolated from a fish processing plant. J. Food Prot. 2013, 76, 1179-1186. [CrossRef]

55. Moltz, A.G.; Martin, S.E. Formation of biofilms by Listeria monocytogenes under various growth conditions. J. Food Prot. 2005, 68, 92-97. [CrossRef] [PubMed]

56. Kastbjerg, V.G.; Laesen, M.H.; Ingmer, H. Influence of sublethal concentrations of common disinfectants on expression of virulence genes in Listeria monocytogenes. Appl. Environ. Microbiol. 2010, 76, 303-309. [CrossRef] [PubMed]

57. Srey, S.; Jahid, I.K.; Ha, S.D. Biofilm formation in food industries: A food safety concern. Food Control. 2013, 31, 572-585. [CrossRef]

58. Schlafer, S.; Meyer, R.L. Confocal microscopy imaging of the biofilm matrix. J. Microbiol. Methods 2017, 138, 50-59. [CrossRef]

59. Gómez, D.; Azón, E.; Marco, N.; Carramiñana, J.J.; Rota, C.; Ariño, A.; Yanguela, J. Antimicrobial resistance of Listeria monocytogenes and Listeria innocua from meat products and meat-processing environment. Food Microbiol. 2014, 42, 61-65. [CrossRef] [PubMed]

60. Jahid, I.K.; Ha, S.D. The paradox of mixed-species biofilms in the context of food safety. Compr. Rev. Food Sci. Food Saf. 2014, 13, 990-1011. [CrossRef]

61. Metselaar, K.; Ibusquiza, P.S.; Ortiz, C.A.R.; Krieg, M.; Zwietering, M.H.; den Besten, H.M.; Abee, T. Performance of stress resistant variants of Listeria monocytogenes in mixed species biofilms with Lactobacillus plantarum. Int. J. Food Microbiol. 2015, 213, 24-30. [CrossRef]

62. International Organization for Standardization (ISO). 1290-1:1996. Microbiology of Food and Animal Feeding Stuffs-Horizontal Method for the Detection and Enumeration of Listeria monocytogenes; Part 1: Detection Method; International Organization for Standardization: Geneva, Switzerland, 1996.

63. Graves, L.M.; Swaminathan, B. PulseNet standardized protocol for subtyping Listeria monocytogenes by macrorestriction and pulsed-field gel electrophoresis. Int. J. Food Microbiol. 2001, 65, 55-62. [CrossRef]

64. European standard (EN). 1276:2009. Chemical Disinfectants and Antiseptics-Quantitative Suspension Test for the Evaluation of Bactericidal Activity of Chemical Disinfectants and Antiseptics Used in Food, Industrial, Domestic and Institutional Areas-Test Method and Requirements (Phase 2, Step 1); International Organization for Standardization: Geneva, Switzerland, 2009.

(C) 2020 by the authors. Licensee MDPI, Basel, Switzerland. This article is an open access article distributed under the terms and conditions of the Creative Commons Attribution (CC BY) license (http://creativecommons.org/licenses/by/4.0/). 